\title{
PENERAPAN PENGASAPAN CAIR PADA PENGOLAHAN ABON ROA (Hemirhamphus sp.) DAN PAMPIS CAKALANG (Katsuwonus pelamis L) DAN MUTU MIKROBIOLOGIS PRODUK YANG DIKEMAS MODIFIED ATMOSPHERIC PACKAGING (MAP)
}

\author{
Chintia S F Bawole ${ }^{1}$, Feny Mentang ${ }^{2}$ dan Henny Dien ${ }^{2}$ \\ ${ }^{1)}$ Mahasiswa pada Program Studi Teknologi Hasil Perikanan FPIK Unsrat Manado \\ 2) Staf pengajar pada Program Studi Teknologi Hasil Perikanan FPIK Unsrat Manado \\ Email: chintia.bawole@yahoo.com
}

\begin{abstract}
Smoked Garp fish and smoke Skipjack a typical processed product in North Sulawesi. Roa smoke and smoke Skipjack can be further processed into abon Roa and Skipjack pampis, abon fish are foods processed fish flavored, processed by boiling and frying obtain dry product, while pampis fish is processed product of smoke Skipjack flavored and obtain the product half wet. The purpose of this study is to see and observe the presence of bacteria on the product abon Roa and Skipjack pampis are packed Modified Atmospheric Packaging (MAP) and stored at room temperature for 30 days. Total Plate Count (TPC),total of Salmonella sp., total E. coli and total Vibrio sp. observed every 10 days, at 0, 10, 20, and 30 days of storage. Based on observations Total Plate Count, abon Roa and Skipjack pampis can last for 30 days with the highest TPC value of $6.3 \times 10^{4} \mathrm{CFU} / \mathrm{g}$ and still be consumed. While Total Salmonella sp, total E. coli and total Vibrio sp. indicates a negative value to the day to 30 has a negative value.
\end{abstract}

Keyword: Microbiological quality, abon Roa, Skicjack pampis, MAP packaging.

Roa asap dan Cakalang fufu merupakan produk olahan ikan asap khas Sulawesi Utara. Roa asap dan Cakalang $f u f u$ dapat diolah lebih lanjut menjadi abon roa dan pampis cakalang, abon ikan merupakan jenis makanan olahan ikan yang diberi bumbu, diolah dengan cara perebusan dan penggorengan yang memperoleh produk kering, sedangkan pampis ikan adalah produk olahan dari cakalang fufu yang diberi bumbu dan memperoleh produk setengah basah. Tujuan penelitian ini yaitu untuk melihat dan mengamati keberadaan bakteri pada produk abon Roa dan pampis Cakalang yang dikemas Modified Atmospheric Packaging (MAP) dan disimpan pada suhu ruang selama 30 hari. Angka Lempeng Total (ALT), total Salmonella sp, total E. coli dan total Vibrio sp diamati setiap 10 hari yaitu pada 0, 10, 20, dan 30 hari penyimpanan. Berdasarkan hasil pengamatan Angka Lempeng Total, abon Roa dan pampis Cakalang dapat bertahan selama 30 hari dengan nilai ALT tertinggi 6,3×10 $\mathrm{CFU} / \mathrm{g}$ dan masih bisa dikonsumsi. Sedangkan Total Salmonella sp, total E. coli dan total Vibrio sp menunjukkan nilai negatif sampai pada hari ke 30 memiliki nilai negatif.

Kata Kunci: Mutu mikrobiologis, abon Roa, pampis Cakalang, kemasan MAP.

\section{PENDAHULUAN}

Ikan merupakan salah satu sumber makanan yang sangat dibutuhkan oleh manusia karena banyak mengandung protein.Kandungan protein dan air yang terdapat pada ikan cukup tinggi, sehingga ikan termasuk komoditi yang mudah busuk. Oleh karena itu, diperlukan upaya untuk menghambat proses pembusukan dengan cara pengawetan dan pengolahan. Pengolahan ikan dengan cara pengasapan bertujuan untuk mengawetkan memberi aroma yang sedap, warna kecoklatan, tekstur yang bagus serta cita rasa yang khas dan lezat pada daging ikan yang diolah. Ikan asap menjadi awet karena adanya pengurangan kadar air akibat dari proses pengasapan dan adanya senyawa-senyawa kimia di dalam asap seperti fenol, karbonil dan asam organik yang dapat menghambat pertumbuhan mikroorganisme serta berperan sebagai antioksidan. Pengolahan ikan Roa asap dan Cakalang asap di Sulawesi Utara sudah dilakukan secara turun-temurun dengan metode pengasapan yang konvensional. Disamping itu ikan Roa asap dan Cakalang asap dapat diolah lebih lanjut menjadi abon roa dan pampis cakalang, produk yang juga banyak digemari oleh masyarakat lokal maupun dari luar Manado. 
Menurut Karyono dan Wachid (1982), abon ikan adalah produk olahan hasil perikanan yang dibuat dari daging ikan, melalui kombinasi dari proses penggilingan, penggorengan, pengeringan, serta penambahan bahan pembantu dan bahan penyedap terhadap daging ikan. Pampis Cakalang adalah salah satu produk turunan Cakalang $f u f u$, dimana makanan olahan dari ikan Cakalang $f u f u$ ini sangat disukai dan digemari oleh masyarakat terutama bagi masyarakat Sulawesi Utara. Produk pampis cakalang asap pada umumnya dihasilkan oleh industri rumah tangga skala kecil dan produk umumnya dikemas dalam wadah toples gelas, wadah plastik dan pengemasan lain yang masih sederhana. Pengemasan adalah suatu cara atau suatu perlakuan pengamanan terhadap bahan atau produk agar bahan atau produk tersebut baik yang belum maupun yang sudah mengalami pengolahan sampai ke tangan konsumen dengan baik. Pengemasan atmosfir termodifikasi (MAP) adalah pengemasan produk dengan menggunakan bahan kemasan yang dapat menahan keluar masuknya gas sehingga konsentrasi gas di dalam kemasan berubah dan ini menyebabkan laju respirasi produk menurun, mengurangi kerusakan oleh enzim, memperpanjang umur simpan dan mengurangi pertumbuhan bakteri. Bakteri patogen yang berada dalam bahan pangan pada umumnya yaitu Salmonella sp, Staphylococcus aureus dan Escherichia coli (Supardi dan Sukamto 1999).

Salmonella sp merupakan bakteri batang gram-negatif. Karena habitat aslinya yang berada di dalam usus manusia maupun binatang, bakteri ini dikelompokan ke dalam enterobacteriaceae (Brooks, 2005). Bakteri Salmonella sp merupakan mikrobia patogen penyebab sakit perut yang dapat menyebabkan kematian, yang disebut sebagai Salmonellosis. Menurut volk dan wheeler (1990) bahwa jenis Salmonella yang paling sering menyebabkan infeksi adalah S. typhimurium, S. newport dan S. entertidis. Salmonella mungkin menyebabkan gastroenteritis setelah 8-48 jam setelah mengkonsumsi makanan yang tercemar dengan Salmonella. Gejalanya ditandai dengan rasa sakit perut mendadak disertai diare encer atau berair, seringkali mual dan muntah-muntah juga dengan suhu $38-39^{\circ} \mathrm{C}$.

Escherichia coli merupakan bakteri gram negatif berbentuk batang pendek yang memiliki panjang sekitar $2 \mu \mathrm{m}$, diameter 0,7 $\mu \mathrm{m}$, lebar $0,4-0,7 \mu \mathrm{m}$ dan bersifat anaerob. Escherichia coli membentuk koloni yang bundar, cembung, dan halus dengan tepi yang nyata (Smith-Keary, 1988 ; Jawetz et al., 1995). Escherichia coli menjadi patogen jika jumlah bakteri ini dalam saluran pencernaan meningkat atau berada di luar usus. E. coli menghasilkan enterotoksin yang menyebabkan beberapa kasus diare.

Vibrio sp adalah genus bakteri gram negatif, sel tunggal berbentuk batang pendek yang bengkok (koma), berukuran panjang 1,45,0 $\mu \mathrm{m}$ dan lebar $0,3-1,3 \mu \mathrm{m}$, bersifat motil dan mempunyai flagel polar dan secara khas ditemukan pada air laut. Vibrio sp bersifat anaerob fakultatif, yaitu dapat hidup baik dengan atau tanpa oksigen. Semua anggota jenis Vibrio sp adalah motil (bergerak) dan mempunyai kutub flagella dengan sarung pelindung (Michel J. Pelczar, 1986). Vibrio sp merupakan salah satu bakteri patogen yang tergolong dalam divisi bakteri yang dapat menyebabkan kematian biota laut yang menghuni perairan, dan secara tidak langsung bakteri yang terbawa biota laut seperti ikan akan dikonsumsi oleh manusia, sehingga menyebabkan penyakit pada manusia (Feliatra, 1999).

\section{METODOLOGI PENELITIAN}

Metode yang digunakan dalam penelitian ini adalah metode eksperimen yaitu mengungkapkan fakta-fakta berdasarkan permasalahan yang ada melalui pengujian hipotesa. Gay (1981), menyatakan bahwa metode penelitian yang dapat menguji secara benar hipotesis menyangkut hubungan sebabakibat.

\section{Bahan}

Abon Roa, pampis Cakalang, kemasan MAP, alkohol $70 \%$ dan 95\%, akuades $10 \%$, $\mathrm{NaCl} 0,9 \%$, media Nutrient Agar, media Bismuth Sulfite Agar, media Escherichia coli Broth, media APW (peptone 1\%, $\mathrm{NaCl} 1 \%$ ), kertas label, gas nitrogen.

\section{Alat \\ Gelas ukur, tabung reaksi, pipet ukur $(1 \mathrm{ml})$, erlenmeyer $(250 \mathrm{ml}$ dan $1000 \mathrm{ml})$, autoclave, tabung Hach, tabung Durham, petridis, spatula, beaker gelas, kompor gas, wajan, baki, keranjang, gunting, magnetic stirer, inkubator, thermometer, timbangan}


analitik, oven, lampu spritus, lemari penyimpanan.

\section{Perlakuan}

Dalam penelitian ini perlakuan yang akan digunakan; yaitu:

Perlakuan Bahan (A):

$\mathrm{A}_{1}$ : Abon Roa

$\mathrm{A}_{2}$ : Pampis Cakalang

Perlakuan Penyimpanan (B) :

$$
\begin{aligned}
& \mathrm{B}_{1}: 0 \text { hari } \\
& \mathrm{B}_{2}: 10 \text { hari } \\
& \mathrm{B}_{3}: 20 \text { hari } \\
& \mathrm{B}_{4}: 30 \text { hari }
\end{aligned}
$$

\section{HASIL DAN PEMBAHASAN}

\section{Analisa Angka Lempeng Total (ALT)}

Data hasil analisis ALT abon Roa dan pampis Cakalang yang dikemas menggunakan Modified Atmospheric Packaging (MAP) dan disimpan pada suhu ruang dapat dilihat pada tabel 1 .

Tabel 1. Data hasil analisis ALT abon Roa dan pampis Cakalang yang dikemas menggunakan Modified Atmospheric Packaging (MAP) dan disimpan pada suhu ruang.

\begin{tabular}{cccccc}
\hline \multirow{2}{*}{ Sampel } & \multirow{2}{*}{$\begin{array}{c}\text { Ulang- } \\
\text { an }\end{array}$} & $\begin{array}{c}\text { Penguji- } \\
\text { an } \mathbf{H}_{\mathbf{0}}\end{array}$ & $\begin{array}{c}\text { Penguji- } \\
\text { an } \mathbf{H}_{\mathbf{1 0}}\end{array}$ & $\begin{array}{c}\text { Penguji- } \\
\text { an } \mathbf{H}_{\mathbf{2 0}}\end{array}$ & $\begin{array}{c}\text { Penguji- } \\
\text { an } \mathbf{H}_{\mathbf{3 0}}\end{array}$ \\
\cline { 3 - 6 } & 1 & $3,1 \times 10^{2}$ & \multicolumn{4}{c}{ Nilai ALT $(\mathbf{C F U} / \mathbf{g})$} \\
\hline Abon & $1,0 \times 10^{3}$ & $5,2 \times 10^{3}$ & $3,0 \times 10^{4}$ \\
Roa & 2 & $5,9 \times 10^{2}$ & $3,0 \times 10^{3}$ & $2,9 \times 10^{4}$ & $6,3 \times 10^{4}$ \\
\hline Pampis & 1 & $3,6 \times 10^{2}$ & $8,1 \times 10^{2}$ & $7,0 \times 10^{3}$ & $3,6 \times 10^{4}$ \\
Cakalang & 2 & $4,8 \times 10^{2}$ & $3,6 \times 10^{3}$ & $3,1 \times 10^{4}$ & $1,0 \times 10^{4}$ \\
\hline
\end{tabular}

Berdasarkan hasil analisis, abon Roa pada pengujian hari ke-0 memiliki nilai ALT $3,1 \times 10^{2}$ dan $5,9 \times 10^{2} \mathrm{CFU} / \mathrm{g}$. Pampis Cakalang memiliki nilai ALT $3,6 \times 10^{2} \mathrm{CFU} / \mathrm{g}$ dan $4,8 \times 10^{2}$ $\mathrm{CFU} / \mathrm{g}$. Pada analisis hari ke-10, abon Roa memiliki nilai ALT 2,0x $10^{3} \mathrm{CFU} / \mathrm{g}$ dan $3,0 \times 10^{3}$. Pampis Cakalang memiliki nilai ALT $8,1 \times 10^{2}$ $\mathrm{CFU} / \mathrm{g}$ dan $3,6 \times 10^{3}$. Pengujian hari ke-20, abon Roa memiliki nilai ALT $5.2 \times 10^{3}$ dan $2,9 \times 10^{4}$. Pampis Cakalang memilki nilai ALT $7,0 \times 10^{3}$ dan $3,1 \times 10^{4}$. Pengujian hari ke-30 telah terjadi peningkatan ALT abon Roa memiliki nila ALT $3,0 \times 10^{4}$ dan $6,3 \times 10^{4}$. Pampis Cakalang memiliki nilai ALT $3,6 \times 10^{4}$ dan $1,0 \times 10^{4}$.

Besarnya jumlah bakteri ini kemungkinan disebabkan oleh pada penyimpanan hari ke 0 bakteri baru mulai beradaptasi dengan lingkungannya yang baru, dimana bakteri mampu bertahan hidup walaupun belum dapat berkembang biak.
Dengan demikian produk abon Roa dan pampis Cakalang dengan menggunakan bahan kemasan MAP yang dapat menahan keluar masuknya gas sehingga konsentrasi gas di dalam kemasan berubah dan ini yang menyebabkan umur simpan produk bisa bertahan, namun berdasarkan persyaratan mutu cakalang asap yang dikeluarkan oleh Badan Standarisasi Nasional Indonesia tahun 2009 jumlah bakteri maksimum $1,0 \times 10^{5} \mathrm{CFU} / \mathrm{gr}$, hal ini berarti jumlah bakteri pada abon Roa dan pampis Cakalang pada penyimpanan hari ke-30 pada temperatur ruang masih layak dikonsumsi. Menurut Moeljanto (1992) baik dan buruknya penanganan sangat menentukan mutu ikan sebagai bahan mentah untuk pengolahan lebih lanjut. Mutu dari suatu produk akhir akan ditentukan oleh keadaan sanitasi dan higienis dari bahan mentah, selama pengolahan hingga menjadi produk akhir (Ilyas, 1972). Pada penyimpanan 30 hari terjadi peningkatan nilai koloni bakteri, hal ini disebabkan bakteri mulai bertumbuh dan berkembang biak. Hal ini dipertegas oleh Buckle $d k k$. (1985), bahwa pada tahap awal pertumbuhan mikroorganisme belum terjadi pembelahan sel. Selanjutnya setelah mampu beradaptasi dengan lingkungannya yang baru, sel-sel bakteri akan tumbuh dan membelah secara eksponil sampai jumlah yang maksimum.

\section{Analisis Total Salmonella sp.}

Hasil analisa menunjukkan total Salmonella sp pada abon Roa dan pampis Cakalang yang dikemas MAP dan disimpan pada temperatur ruang selama penyimpanan 0 , 10, 20 dan 30 hari adalah negatif. Hal ini menunjukkan bahwa abon Roa dan pampis Cakalang yang dipakai sebagai bahan penelitian cukup baik. Salmonella bersifat aerob dan anerob fakultatif sehingga pengemasan secara MAP sangat baik digunakan untuk menghambat pertumbuhan salmonella karena prinsip dari pengemasan MAP adalah kemasan yang dapat menahan keluar masuknya gas sehingga konsentrasi gas di dalam kemasan berubah dan ini menyebabkan laju respirasi menurun, mengurangi pertumbuhan mikroba, mengurangi kerusakan oleh enzim serta memperpanjang masa simpan. Hal ini juga menyatakan bahwa dalam pengolahan abon Roa dan pampis Cakalang dilakukan secara tepat dimana sanitasi dan higienis tetap terjaga. 
Analisis Total Koliform dan Escherichia coli

Pengujian total koliform dan total $E$. coli pada abon Roa dan pampis Cakalang yang dikemas menggunakan MAP dan disimpan pada temperatur ruang selama penyimpanan $0,10,20$ dan 30 hari, memiliki nilai negatif. Hal tersebut menunjukkan bahwa abon Roa dan pampis Cakalang yang dikemas menggunakan MAP dan disimpan pada temperatur ruang masih dapat diterima oleh SNI 2009 dengan persyaratan keamanan mutu cakalang asap dimana E. coli maksimal $<3$ APM/gr. E. coli adalah anggota flora normal usus, $E$. coli berperan penting dalam sintesis vitamin $\mathrm{K}$, konversi pigmen-pigmen empedu, asam-asam empedu dan penyerapan zat-zat makanan. E. coli termasuk ke dalam bakteri heterotrof yang memperoleh makanan berupa zat organik dari lingkungannya karena tidak dapat menyusun sendiri zat organik yang dibutuhkannya. Zat organik diperoleh dari sisa organisme lain. Di dalam lingkungan, bakteri pembusuk ini berfungsi sebagai pengurai dan penyedia nutrisi bagi tumbuhan (Ganiswarna, 1995). E. coli menjadi patogen jika jumlah bakteri ini dalam saluran pencernaan meningkat atau berada di luar usus. E. coli menghasilkan enterotoksin yang menyebabkan beberapa kasus diare. E. coli berasosiasi dengan enteropatogenik menghasilkan enterotoksin pada sel epitel (Jawetz et al., 1995). Penyakit yang disebabkan oleh E. coli yaitu infeksi saluran kemih dan diare.

\section{Total Vibrio sp}

Hasil pengamatan total vibrio pada abon Roa dan pampis Cakalang yang dikemas mengggunakan MAP dan disimpan pada temperatur ruang selama penyimpanan $0,10,20$ dan 30 hari, memiliki nilai negatif. Hal ini menunjukkan bahwa abon Roa dan pampis Cakalang yang dipakai sebagai bahan penelitian cukup baik karena walaupun tidak disimpan pada temperatur dingin hasil uji total koliform dan total vibrio adalah negatif, hal ini berarti dalam pengolahan abon Roa dan pampis Cakalang dilakukan secara tepat dengan sanitasi dan higienis yang tetap terjaga. Sehingga abon Roa dan pampis Cakalang yang dikemas menggunakan MAP dan disimpan pada temperatur ruang masih dapat diterima oleh SNI 2009 dimana vibrio harus negatif.

\section{KESIMPULAN}

1. Berdasarkan hasil penelitian yang dilakukan dapat disimpulkan bahwa Angka Lempeng Total (ALT) dari abon Roa dan pampis Cakalang yang dikemas MAP dan disimpan pada temperatur ruang masih layak dikonsumsi sampai pada penyimpanan 30 hari.

2. Total Salmonella sp, total koliform, total $E$. coli dan Vibrio sp abon Roa dan pampis Cakalang yang dikemas MAP adalah nilainya negatif.

3. Pengemasan dengan MAP dapat mempertahankan mutu secara mikrobiologis dan memperpanjang masa simpan selama 30 hari berdasarkan total ALT.

\section{SARAN}

1. Perlu dilakukan penelitian perbandingan keberadaan mikroba pada penyimpanan temperatur dingin dan temperatur ruang.

2. Perlu dilakukan pengamatan dengan masa simpan antara 1-3 bulan untuk melihat pertumbuhan bakteri yang terjadi.

3. Perlu adanya SNI produk olahan khususnya abon Roa dan pampis Cakalang.

\section{DAFTAR PUSTAKA}

Brooks, G.F., Butel, J.S., Morse, S.A., 2005. Mikrobiologi Kedokteran, Edisi 23. Jakarta: Penerbit Buku Kedokteran ECG: 317-27

Buckle, K. A. Edwards, R. A., Flet, G. H,.Wootlon, M 1987. Ilmu Pangan. Diterjemahkan oleh Hari Purnomo dan Adiono. UI. Press. Jakarta

Feliatra 1999.Identifikasi bakteri patogen (Vibrio sp) di perairan Nongsa Batam, Provinsi Riau. J Natur Indones II (1): 28-33.

Ganiswarna S. G, 1995, Farmakologi dan Terapi, ed. 4, UI-Fakultas Kedokteran, Jakarta.

Ilyas, S, 1983. Teknologi Refrigasi Hasil Perikanan. Jilid 1. Teknik Pendinginan Ikan. C. V. Paripurna, Jakarta.

Jawetz E., J. L. Melnick, E. A. Adelberg, G. F. Brooks, J. S. Butel, L. N. Ornston, 1995, Mikrobiologi Kedokteran, ed. 20, University of California, San Francisco.

Karyono dan Wachid. 1982. Petunjuk Praktek Penanganan dan Pengolahan Ikan. Departemen Pendidikan dan Kebudayaan. Jakarta.

Michel J. Pelczar, Jr dan E.C.S Chan, 1986. Dasar-dasar Mikrobiologi 1. Jakarta: UI Press.

Moeljanto, R. 1992. "Pengawetan dan Pengolahan Hasil Perikanan". Penerbit Swadaya. Jakarta

Smith-Keary P. F., 1988, Genetic Elements in Escherichia coli, Macmillan Molecular biology series, London, p. 1-9, 49-54 
Supardi, I. dan Sukamto, 1999.Mikrobiologi dalam Pengolahan dan Keamanan Pangan. Alumni, Bandung. 